\title{
The Imperata grasslands of tropical Asia: area, distribution, and typology
}

\begin{abstract}
The rehabilitation or intensified use of Imperata grasslands will require a much better understanding of their area, distribution, and characteristics. We generated estimates of the area of Imperata grasslands in tropical Asia, and suggested a typology of Imperata grasslands that may be useful to define the pathways toward appropriate land use intensification. We conclude that the area of Imperata grasslands in Asia is about 35 million ha. This about $4 \%$ of the total land area. The countries with the largest area of Imperata grasslands are Indonesia (8.5 million ha) and India (8.0 million ha). Those with the largest proportion of their surface area covered with Imperata are Sri Lanka (23\%), the Philippines (17\%), and Vietnam (9\%). Laos, Thailand, Myanmar, and Bangladesh evidently all have similar proportions of their land area infested with Imperata (about 3 to 4\%). Malaysia (<1\%), Cambodia (1\%), and the southern part of China $(2 \%)$ have but a minor proportion of their total land area in Imperata. The species was found widely distributed on the full range of soil orders. It occupied both fertile (e.g. some of the Inceptisols and Andisols) and infertile soils (Ultisols and Oxisols) across a wide range of climates and elevations. Imperata lands fall into four mapping scalerelated categories: Mega-grasslands, itmacro-grasslands, meso-grasslands, and micrograsslands. The mega-grasslands are often referred to as óheet Imperataô They are the large contiguous areas of Imperata that would appear on small-scale maps of say 1:1,000,000. We propose that this basic typology be supplemented with a number of additional components that have a key influence on intensification pathways: land quality, market access, and the source of power for tillage. The typology was applied in a case study of Indonesian villages in the vicinity of Imperata grasslands. We propose an international initiative to map and derive a more complete and uniform picture of the area of the Imperata grasslands. This should include selected studies to understand conditions at the local level. These are critical to build the appreciation of change agents for the indigenous systems of resource exploitation, and how they relate to local needs, values and constraints.
\end{abstract}

Keyword: Alang-alang; Area estimates; Cogon; Degraded lands; Imperata cylindrica (L.); Uplands 